\title{
Fra paternalisme til pasientrettigheter
}

\author{
Valgfrihet og pasientrettigheter er viktige idealer i dagens samfunn. I helsevesenet får legene og andre \\ helseprofesjoner mindre å si, mens pasientene, juristene og administratorene får mer. Fordelingen av helse- \\ tjenester blir ikke mer rettferdig og folkehelsen ikke bedre av den grunn.
}

> Se også side 384

\author{
Leif Arne Heløe \\ leif.heloe@nibr.no \\ Norsk institutt for by- og regionforskning \\ Gaustadalleen 21 \\ Oslo
}

Tidligere helsedirektør Karl Evang (1902 81) sto for et sterkt statlig ansvar i helsepolitikken. Han var kritisk til rettsliggjøringen og kravene om større rettigheter til pasientene. Evang, og flere med ham, mente at profesjonene, spesielt legene, var bedre forvaltere av folkehelsen enn folk selv var.

Regelverket for helsetjenesten bygde den gang hovedsakelig på behandlingsmodellen. Den skilte seg klart fra rettighetsmodellen (med individuelle rettigheter), som dagens trygdelovgivning og etter hvert også helselovgivningen legger til grunn (1). Tidligere hadde legene vide fullmakter, blant annet til å treffe beslutninger og fordele tjenestene på grunnlag av faglige og etiske vurderinger. Evang mislikte at økonomer, jurister og politikere blandet seg inn i helsevesenets styre og stell. Ved flere anledninger uttalte han seg kritisk om deres virke. «Amatørvesen» kalte han slikt (2) og mente at avgjørelser burde ligge hos fagfolkene (3). Forvaltningslov og pasientrettigheter smakte ham ikke.

Paternalismen rådde lenge grunnen i helsevesenet, og ikke bare i Norge. Profesjonene gikk på statens vegne inn i folk liv og fortalte dem hvordan det skulle leves. Ved gjennomføringen av pasientrettighetsloven av 1999 og innføring av autonomiprinsippet fikk paternalismen sitt grunnskudd når det gjelder medisinsk behandling.

Fra medisinsk til juridisk tenkemåte Styrkeforholdene mellom behandler og pasient- og profesjonsgruppene seg imellom er endret betydelig siden Evangs dager. En juridisk tenkemåte har tatt over der det medisinske fagskjønnet tidligere rådde grunnen, blant annet når det gjelder fordeling av helsetjenester og prioritering av pasientgrupper. Rettsliggjøringen av helsepolitikken er én av forklaringene på at antall årsverk i den sent- rale helseadministrasjonen er 3-4 doblet i løpet av 30 år.

I 1990-årene vant tankene fra en ny ledelsesfilosofi, «new public management», innpass i flere offentlige tjenestegrener med slagord som effektivitet, regelforenkling, fornying og omstilling. Målstyring kom i tillegg til eller erstattet regelstyringen. Tankegangen ble bygd inn i sykehusreformen av $2001 \mathrm{og}$ organiseringen av helseforetakene. Økonomer og administratorer fikk større innflytelse.

\section{Rettsliggjøring og valgfrihet}

Rettsliggjøringen av helse- og sosialpolitikken kan oppfattes som forløperen for valgfrihet som politisk ideal. Ved overgangen fra sosialhjelpstat til velferdsstat ble behovsprøving etter den annen verdenskrig gradvis erstattet av rettighetsbasert lovgivning (4). Eksempler på det er aldertrygd, uføretrygd, attføring, enke- og morstrygd og universell alderstrygd/pensjon, som alle ble innarbeidet i folketrygdloven av 1966 . Den skiftende politiske tenkemåten og de historiske utviklingslinjene avspeiles blant annet i omtalen av målgruppene i helseog sosialtjenesten. Først het det de fattige, så de nødstedte, de trengende, etter hvert klientene, de trygdede, tjenestemottakerne - og nå: pasientene, beboerne, brukerne og kundene.

Valgfrihet for individet innenfor velferdssektoren er betydelig utvidet i løpet
Europaparlamentet et nytt direktiv om pasientrettigheter ved «grensekryssende helsetjenester». Etter dette kan en pasient søke behandling i utlandet og få kostnadene betalt av hjemlandet - såfremt behandlingen representerer en del av tjenestetilbudet $i$ vedkommendes eget land. Valgfriheten er et stykke på vei utvidet når det gjelder typer av terapi og terapeuter: Kiropraktorer og manuellterapeuter fikk nylig rett til å behandle pasienter på folketrygdens regning ved muskel- og skjelettplager uten henvisning fra lege - og til å sykmelde.

Valgfriheten gjelder langt på vei også pensjoneringsalder, valg mellom offentlige og private omsorgstjenester og mellom barnehager og foreldreomsorg (kontantstøtteordningen). Sistnevnte ordning er omstridt. I 2011 fjernet regjeringen kontantstøtten for toåringer. Omstridt er også tolkingen av det politiske slagordet «pengene skal følge pasienten». Politisk strid står det likeledes om retten til å velge behandlingssted: ved et offentlig eid sykehus, ved et kommersielt drevet eller ved sykehus/institusjoner eid og drevet av ideelle organisasjoner.

Valgfrihet som politisk ideal kom for alvor på dagsordenen i Norge etter at det skandinaviske sosialdemokratiet i 1980årene mistet $\sin$ «hegemoniske posisjon» (5). Frihetsidealet fortrengte langt på vei likhetsidealet. Det ble reist krav om supplerende, privatdrevne servicetilbud på sam-

\section{«En juridisk tenkemåte har tatt over der det medisinske fagskjønnet tidligere rådde grunnen, blant annet når det gjelder fordeling av helse- tjenester og prioritering av pasientgrupper»}

av det siste tiåret. Fra 2001 er det - i det minste på papiret - fritt sykehusvalg innenfor helseforetakssystemet. EUs helsedirektiv fastslår at valgfrihet skal gjelde over landegrensene. I januar 2011 godkjente funnsområder som til da hadde vært forbeholdt offentlige tjenesteytere.

Men fortsatt er partiene på venstresiden i utgangspunktet motstandere av konkurranseutsetting og «privatisering» av tjenestepro- 


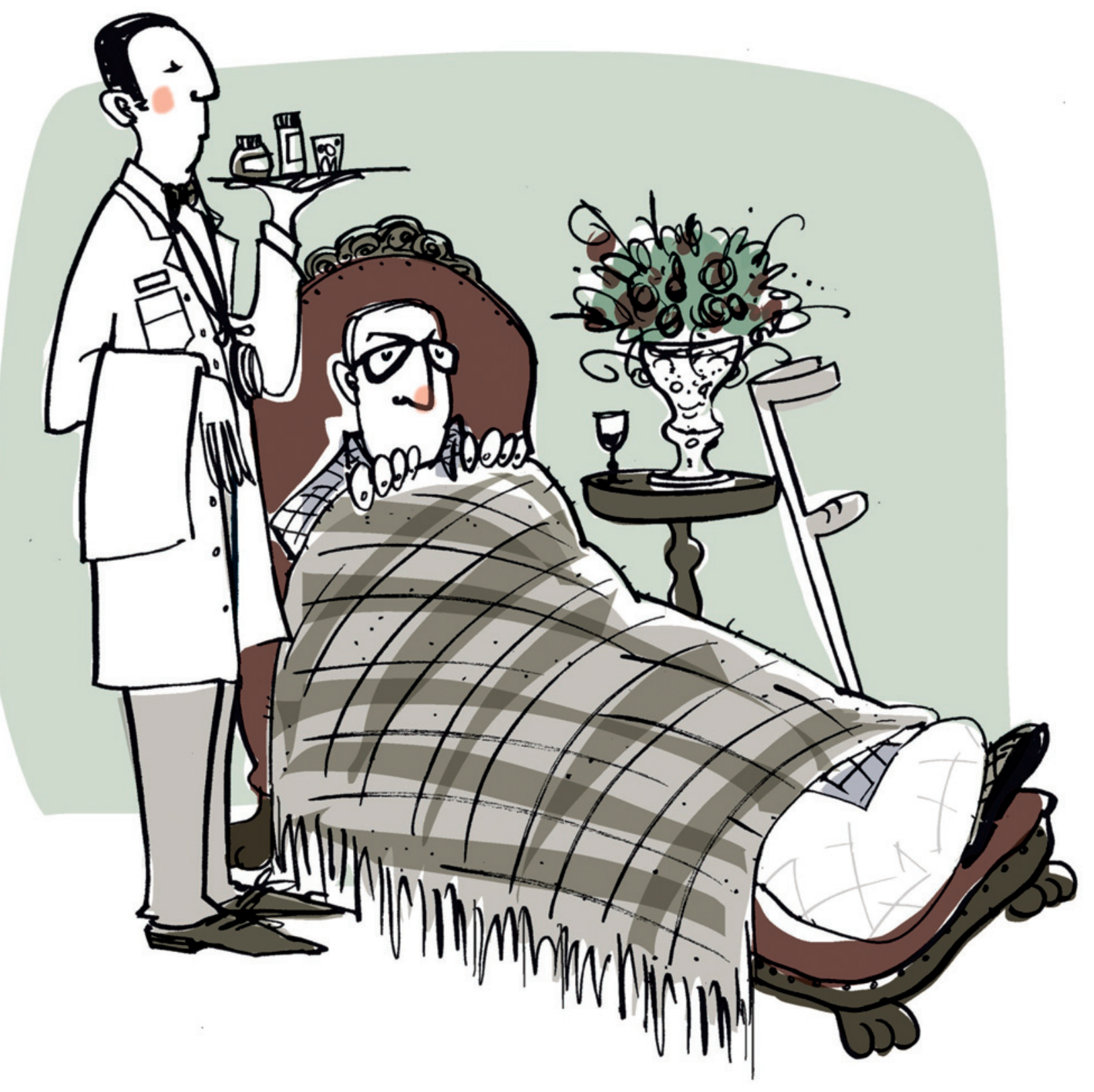

Illustrasjon Supernøtt popsløyd

duksjonen. Det gjelder for eksempel etablering av private sykehus og sykehjem. De stiller seg tidvis også kritisk til privat betaling for helse- eller omsorgstjenester, bl.a. egenbetaling ved tjenester fra offentlig eller privat tjenesteyter, slik som poliklinisk behandling, fastlege, hjemmesykepleie mv. Likevel har disse partiene i regjeringsposisjon økt egenbetalingen («egenandelene»). Generelt gjelder at den politiske høyresiden er pådrivere i prosessen med større valgfrihet på helse- og omsorgsmarkedet. Venstresiden følger nølende og nødtvungent etter.

\section{Rettigheter og plikter}

Helselovgivningen og trygdelovgivningen legger ulikt perspektiv på forholdet mellom rett, plikt og eventuelle sanksjoner. Mens rettigheter til helse- og omsorgstjenester lovfestes uten nevneverdig vekt på plikter, kan trygdeytelser stanses eller nektes hvis pasienten uten rimelig grunn lar være å følge legens råd eller viser grov skjødesløshet med egen helse (folketrygdloven $\S$ 21-8) (1). Misbruker vi rettighetene, for eksempel ved å lure til oss ytelser som ikke tilkommer oss, reagerer samfunnet med krav om tilbakebetaling og straff. Dagens helselovgivning har ingen tilsvarende bestemmelser om pasienters plikter og/eller om sanksjoner.

Helsepersonellet får stadig flere plikter. I lov om lægers rettigheter og plikter av 1927 var rettighetene og pliktene noenlunde jevnt fordelt. Som jusprofessor Asbjørn Kjønstad skriver: «Legeloven av 1980 inneholdt ca. 10 bestemmelser om legers rettigheter og ca. 20 bestemmelser om legenes plikter, mens pliktene er helt dominerende i helsepersonelloven av 1999» (1).

I et innlegg i Tidsskriftet nylig etterspurte lege Håkon Lie et supplement til ret- tighetslovgivningen med bestemmelser om plikt for pasientene til å være sannferdige og samarbeide etter beste evne (6). Han er ikke den eneste som har etterlyst regler for pasienters egenansvar. Under forarbeidet med kommunehelseloven i 1980 foreslo utrederen, tidligere høyesterettsdommer Trygve Leivestad (1907-94), en klok jurist med stor innsikt i legeetikk og moralfilosofi, at pasientens rettigheter burde ledsages av plikter: Rettighetene burde betinges av at pasienten rettet seg etter legens anvisninger. Leivestad ønsket formodentlig å overføre prinsipper fra trygdelovgivningen til å gjelde også kommunehelseloven.

Forslaget vant ikke gehør i departementet. På dette punktet ble Leivestads forslag lagt til side. Å innføre en «plikt» til å følge legens råd vil - etter dagens lovgivning - være i strid med autonomiprin- 
sippet. Men kanskje kan trygdelovgivningens pålegg om plikter forenes med autonomiprinsippet gjennom et kompromiss. Grov skjødesløshet med egen helse kan for eksempel være en faglig begrunnelse for reduserte rettigheter til enkelte behandlingstyper.

\section{Folketrygd og valgfrihet}

Slagordet «pengene skal følge pasienten» markerer et ytterpunkt i debatten om valgfrihet på helsemarkedet. Et grunnleggende spørsmål er da hvordan disposisjonsretten over trygdemidlene er å forstå. Satt på spissen: Hvem «eier» folketrygden? Er midlene å regne som «våre egne», som vi i samråd med lege langt på vei selv skal kunne bruke av til helseformål under mottoet «pengene skal følge pasienten»?

Carl I. Hagen har foreslått å overføre det økonomiske ansvaret for eldreomsorgstjenestene fra kommunene til folketrygden (7). Dermed vil behovet - og ikke den kommunale økonomien - avgjøre tjenestetilbudet, mener han. Trolig vil mange se med sympati på et slikt forslag, blant annet fordi pasientene tilsynelatende vil stille likt, uansett bosted. Kanskje vil også pasientenes valgfrihet når det gjelder behandlingssted øke - vel å merke i kommuner der tjenestetilbudene er flere. Men $i$ årene fremover vil mangelen på kvalifisert personell i eldreomsorgen utgjøre et minst like stort problem som den kommunale økonomien. Antall arbeidstakere per pensjonist vil gå ned fra fem i 2010 til tre i 2050. Behovet for nye årsverk i helse- og omsorgssektoren vil øke med ca. 135000 de nærmeste 20 årene. Valgfrihet innenfor et «omsorgsmarked» der etterspørselen etter tjenester er konstant større enn tilbudet, er langt på vei illusorisk.

Hagens modell med trygdefinansiering av eldreomsorgen likner betalingsordningen for primærlegetjenester før kommunehelsetjenestens og fastlegenes tid. Ordningen ble den gang forlatt nettopp fordi den var kostnadsdrivende og førte til store geografiske forskjeller i tilbudene: Utbetalingene var mer avhengig av legedekningen enn av sykeligheten i befolkningen.

\section{Kvasimarked}

$\AA$ kombinere stor valgfrihet for individet med offentlig betaling av tjenestene er ingen lett øvelse. Folketrygden skiller seg fra private forsikringsordninger ved at den bygger på et «pay-as-you-go»-prinsipp enkelt sagt dekkes utbetalingene fortløpende av skatteinntektene fra de yrkesaktive, mens private forsikringer bygger på egne innskudd, tillagt renter.

Levering av helsetjenester skjer på et kvasimarked, der tredjepart, dvs. det offentlige, betaler i gjennomsnitt vel $80 \%$ av kostnadene. Mens konkurranse på åpne markeder vanligvis bidrar til lavere priser, bidrar kvasimarkeder gjerne til økte utgif- ter. Forbruket vil øke, forutsatt at ikke minst én av tre sperrer settes inn:

- Økonomiske rammer som avgrenser de offentlige utgiftene

- Strengt økonomisk og/eller faglig tilsyn med at midlene brukes i samsvar med hensikten - oftest med mer byråkrati til følge

- Økt egenbetaling for pasientene, med dobbelt siktemål: Lavere etterspørsel kombinert med økte inntekter for tjenesteyteren

Valgfrihet innenfor kollektivt finansierte ordninger er kort sagt ugreit.

\section{Valgfrihet - et middelklassegode}

Lovfestede helse- og sosialpolitiske rettigheter, supplert med valgfrihet, er blant de fremste godene i dagens velferdssamfunn. Overgangen fra sosialhjelpsstat med behovsprøving til velferdsstat med rettigheter bidro til at store befolkningsgrupper fikk sin rettmessige del av samfunnsgodene. Svake grupper slapp «å stå med lua i hånda og be», ble det sagt. Rettighetene medførte «oppjevning» av kårene for gruppene med størst behov for pensjon og offentlige helsetjenester. Siden er rettsliggjøringen blitt supplert med valgfrihet.

Den omfatter i dag ytelser og tjenester som benyttes av langt flere, kanskje særlig av en voksende middelklasse som har råd til den egenbetalingen som kreves for å utløse offentlige ytelser.

Allmenne (universelle) velferdspolitiske ordninger har mange forsvarere. Pasient- og klientorganisasjonene ivrer for normeringer og klare lovregler. Som brukere ønsker vi rettigheter som er klart definert og klubbet i Stortinget. «Moderne, velutdannete borgere vil selv velge mellom offentlige og private tjenester og tror ikke at politikerne er mer ansvarlige og kunnskapsrike en de er selv,» skriver Kristin Clemet (8). Det politiske mantraet «pasienten i sentrum» tilsier at vi skal kunne velge mellom behandlere og behandlinger. Dersom rettighetene ikke oppfylles eller tjenestene oppleves som mangelfulle, skal vi kunne klage.

Blant dem som søker advokathjelp for å fremme sine krav overfor myndighetene, er det neppe overvekt av fattigfolk. Riksrevisjonen har nylig påpekt $\mathrm{i}$ en av sine rapporter at de som tjener mest, har best utdanning og er $\mathrm{i}$ arbeidslivet, er de som mest benytter seg av ordningen med fritt sykehusvalg, ifølge en artikkel i Aftenposten (9). Som påpekt også i Aftenposten skaper «samfunnets rettsliggjøring [...] et stadig større behov for advokatenes ofte svært dyre tjenester» og at «mange advokater er eksperter på å skape grunnlag for ytterligere advokatarbeid» (10).

\section{Fra fag og skjønn til lov og rett}

Juridiske professorer leder lovutredninger som konsekvent ender med at fag og skjønn erstattes av lov og rett. Slik overtar rettssta- tens kodekser områder som før var styrt ved hjelp av helseprofesjonenes tenkemåte og politikkens dagsorden. Rettighetene overvåkes gjennom statlig tilsyn og klageordninger, forvaltet av bl.a. Helsetilsynet og fylkesmennene. Enkeltstående kritikere hevder at Helsetilsynet ikke slår hardt nok ned på feil og unnlatelsessynder i helsevesenet. På Stortinget blir det krevd opprettet en «havarikommisjon» som kan rykke ut dersom tilsynet ikke gjør jobben sin.

Den sosialpolitiske omfordelingseffekten av dagens rettighetsreformer er trolig mindre enn den gang pasient- og klientrettigheter slo gjennom som sosialpolitisk virkemiddel. Utviklingen kan forsvares ut fra velferdsstatens hovedprinsipp om bruk av universelle ordninger som omfatter alle, ikke på bruk av selektive, myntet på de få. Mot dette kan anføres at kampen mot fattigdom neppe kan vinnes - ei heller kan målet om helsemessig likhet $\mathrm{i}$ befolkningen nås - uten å bruke selektive tiltak. Dette må innebære sterkere satsing på tiltak og rettigheter myntet direkte på utsatte grupper $\mathrm{i}$ befolkningen.

\section{Leif Arne Heløe (f. 1932)}

er dr.odont. og forsker (deltid) ved Norsk institutt for by- og regionforskning (NIBR). Han har tidligere vært professor i samfunnsodontologi ved Det odontologiske fakultet, Universitetet i Oslo, sosial- log helse)minister (H) og fylkesmann i Troms.

Ingen oppgitte interessekonflikter.

\section{Litteratur}

1. Kjønstad A. Helserett - pasienters og helsearbeideres rettsstilling. Oslo: Gyldendal, 2007.

2. Nordby T. Karl Evang. En biografi. Oslo: Aschehoug, 1989.

3. Nordby T. Helsedirektør Evangs planer for velferdsstaten. Michael 2009; 6: 331-7.

4. Seip AL. Helse som samfunnssak. I: Seip AL. Sosialhjelpstaten blir til. Norsk sosialpolitikk 1740-1920. Oslo: Gyldendal, 1984.

5. Sejersted F. Den skandinaviske modell. I: Bastiansen HG, Hagtvet B, Hjeltnes G et al, red. Det elegante uromoment. Hans Fredrik Dahl og offentligheten. Oslo: Pax, 2009.

6. Lie H. Hva med pasientplikter? Tidsskr Nor Legeforen 2011; 131: 16

7. Hagen $\mathrm{Cl}$. Folketrygden bør overta. Aftenposten 30.9.2011.

8. Clemet K. Den nye norske modellen. Aftenposten 20.10.2011

9. Dommerud T. Kjennskap og vennskap er avgjørende. Fritt sykehusvalg forsterker klasseskiller. Aftenposten 23.10.2011

10. «Knallår». Leder. Aftenposten 10.1.2011.

Mottatt 29.11.2011 og godkjent 1.12. 2011. Medisinsk redaktør Petter Gjersvik 